\title{
Global Educational policies and its effects on the academic profession in Brazil
}

\author{
José Ronaipe Machado \\ ronaipe@ hotmail.com \\ Our Lady of Carmo, Belém, PA \& Universidade Católica de Brasilia, Brazil
}

\begin{abstract}
This paper discusses the relationships between the current situation of professors of higher education institutions in Brazil and the changes that have come about in the Brazilian educational system as it has been affected and guided by neoliberal ideology principles through influence of International Organizations such as the World Bank and the IMF. Concepts like globalization, global governance and neocolonialism in the field of educational policy making achieve strong relevance as one intends to understand and explain the roots that are in the origins of the situation which academic professorate faces in countries like Brazil as well as in many others across the world. As part of this broader world and global context, Brazilian professors have to face similar, and sometimes even tougher challenges, as educational policies regulated by a new educational act have been implemented in the country throughout the last fifteen years. Under the influence of neoliberal ideas, massification and diversification in the higher education system have led to what many scholars call a state of fragmentation of the academic profession, which is characterized by increasing bureaucratization, heavy accountability requirements, inadequate remuneration and insufficient intellectual preparation to meet academic demands. Accountability and university bureaucratization have reduced teachers' autonomy. The development with the greatest impact on the academic profession is the growing amount of professors with unstable and part-time appointments. As an apparent symptom of the decline of the status of the professoriate, they are paid a low salary to teach a few courses. In such a context, the value of academics is declining and new generations have been unwilling to embrace the academic career. Having well-trained, fairly paid and academically engaged faculty members is as crucial as ever, since countries count on good professors to prepare and form young people to be actively involved in the knowledge-based economy and in the information society.
\end{abstract}

\section{Introduction}

The final result of the ENADE (The National Examination Performance of Students) in Brazil shows that nine out of the top twenty-one students come from private higher education institutions (Jareta, 2010). Teacher quality is among the factors that the students underscore regarding their achievements.

The doctorate dissertation of sociologist Gilson Borda (2007) concluded that a good professor is more valuable than luxury facilities. The opinion is valid for $80 \%$ of the students that he interviewed. This research points out that a professor's qualification is the main factor giving credibility to an institution. Altbach (2009) reinforces the centrality of the professoriate, saying 
that "academic institutions cannot perform well without a committed, well-trained, and stable academic profession."

However, one may argue: "what is a quality teacher"? The answer for such a crucial question both prompts and requires us to look into the status and working conditions of professionals in Higher Education (HE). Among other factors, good teaching performance includes dedicating time to research and teaching, receiving proper academic training, being available to meet students as well as being fully involved in their academic community, both local and international. These elements are better assured when professors hold full-time contracts, have high academic qualification, earn reasonable/adequate remuneration, work in suitable facilities, and participate in decision-making institutional processes. Otherwise professional commitment to educational affairs, to students and to the institution will be at stake. This is exactly what is going on as the number of full-time professors has decreased around the world. In a growing number of countries, Higher Education Institutions (HEI) have been hiring part-time professors who work in different institutions simultaneously (cf. Altbach, Reisberg and Rumbley, 2009). Low salaries have become routine, and are enough only to allow professors to earn the average salary in their countries. In addition, reduced financing, a market-like approach to $\mathrm{HE}$ and accountability demands among other issues have made an unfavorable environment for the academic profession and in turn are causing it to lose its attractiveness among new generations of students.

As part of the global world in which we are found, Brazilian professors are not excluded from that reality. In this sense, this paper intends to ask: what are the links between the current situations which professors face in Brazil and the vast global educational policies along with their ideological trends imposed by international agencies? How do global and national contexts impact educational policies and how do those policies shaped the situation and the quality of life of the professoriate in Brazil? To answer those important questions, this paper draws on a critical reading of educational policies provided by many scholars in order to disclose the means by which those policies affect educators and the realities that universities comprise.

\section{Educational policy and global governance shape the scenario of the academic profession}

It has become commonplace to cast criticism on the professorate and identify them as the source of the several problems which educational systems face. This is an effective ideological way to divert the focus from the most critical and real reasons behind the problems. Universities and academics worldwide have been affected by what Altbach (2009) defines as "the central realities of higher education in the 21 st century: massification, accountability, privatization, and marketization." In his words, massification has led to fragmentation of the academic profession and academic community. Accountability has reduced professional autonomy and more strongly regulated academic work.

Massification as a current global process has provoked an explosion of institutions and tertiary education enrollment development has been accompanied by private sector expansion. Such a phenomenon takes place as neoliberal ideology becomes hegemonic and governments face financial structural adjustments, abstaining from investing in the expansion of the public HE subsystem. Rather, governments have promoted policies that are conducive for private institutions to increase in number. If such policies and tendencies are to be critically understood then one must realize their origins as related to social, cultural, political and economic dynamics which rise above the scenario of its local production (Olsen, Codd and O'Neill, 2004). 
Diversification of institutions and segmentation among the professoriate constitute features of the background that determines the current configuration and trends of the academic profession worldwide. Stromquist, Gil-antón, Colatrella, Mabokela, Smolentseva and Balbachevsky (2007) reinforce this idea by saying that among the consequences of globalization, one that deserves special mention is "the segmentation of quality in the HE systems of many countries and the consequent disparities, often critical, in the working conditions of the professoriate."

Globalization is among the general processes which have impacted educational policies worldwide. Many scholars have warned about the tendency to think of it as unalterable, hegemonic, inexorable, and absolute (Tikly, 2001; Ball, 1988; Santos,2004; Scocuglia, 2006). As those authors recognize "the significance of globalization to questions of national educational and economic development" and that "contracting, deregulation and privatization have reduced, in both practical and ideological terms, the capacity for direct state intervention" (Ball, 1988), they also invite us to perceive that globalization manifests itself in a varied range of aspects far beyond the economic, including demographic, technologic, linguistic, environmental (Bottery, 2006), political and cultural ${ }^{1}$ features (Tikly, 2001) as well as the 'contra-globalizations' (Santos, 2004) $)^{2}$. They see that throughout the process, "a new kind of state is taking shape in the world arena" (Ball, 1998). Within that process, whereas states retain meaningful power within their borders, this power "is being transformed in relation to new institutions of international governance and international law" (Tikly, 2001), so there is a need to overcome the myth of the weak or minimum state, acknowledging that "national governments still hold primary responsibility for providing education" (Tikly, 2001) and "we must still see the see the capacity of individual nation-states (...) to resist the pressures of international capital and the agencies of neoliberal control ${ }^{3} . "$ (Olsen, et al., 2004)

Within such a context, it is noticeable that educational policy making becomes a field of battle, an arena where varied political actors struggle to advocate their interests. Along with the state, the conventional educational policy provider, two new actors have appeared in this arena, namely, the international organizations (IOs) and the market, transforming education into a "field of international and market governance." (Leuze, Martens and Rusconi, 2007) As a result of this process, "the public good of education turns into an international and private good ${ }^{4}$." (idem)

The aforementioned IOs have powerfully impacted educational policies across the world. In this sense, it is obligatory to be aware of the effects that structural adjustment programs imposed by the World Bank ${ }^{5}$ and IMF have on many national policies. Furthermore, the roots of

\footnotetext{
${ }^{1}$ Regarding the cultural aspect, Bottery (2006) argues that by encouraging consumerism globalization affects people's mindset making them "to value the private over the public. Education then becomes useful primarily as means to personal rather than public ends, and notions of "public good' are damaged or destroyed."

${ }^{2}$ Tikly (2001) concurs with Santos by adopting a postcolonial critique perspective which highlights "forms of resistance to Western global hegemony as they have manifested themselves in education" as all of us can currently witness in the Chilean's students protests. In this same line of thought, Olsen, Codd and O'Neill (2004) argue that within our globalized world, "the nation-state is 'too small' to be entirely effective and 'too large' to be entirely irrelevant."

${ }^{3}$ From a neoliberal perspective, rather than providing education service, state has the function to provide the conditions for market education to develop, managing accreditation processes and quality assurance systems, which in turn may threaten public functions of education (Leuze, et al., 2007).

${ }^{4}$ Kohlrausch and Leuze (2007) discuss this crucial topic by analyzing education policies on post-compulsory education in Britain and in Germany.

${ }^{5}$ Leuze et al. (2007) warn that the ideologies which uphold IOs' activities might be contradictory with national goals.
} 
those programs are grounded on principles of neoliberalism and human capital theory ${ }^{6}$ such as these which Tikly (2001) indicates: reduced state educational budget, commercial liberalization policies, government revenue increase by revision of fiscal policies, payment of public services like education by citizens, privatization and marketization ${ }^{7}$ policies among others. Such adjustments intend to increase country's competitiveness by making production less costly.

It is apparent that such structural adjustments create an appalling paradox as it requires the "need for countries to invest in human resource development in order to become globally competitive" and simultaneously calls for cuts in government educational spending (Tikly, 2001). The paradox becomes even more evident in light of Kariwo's (2008) perception: assuming the importance of higher education "as an engine for economic development", the quality of the processes comprised in it is determinant for it "to make a significant contribution", which includes the learning teaching process, where professors play a decisive role. As education represents a critical factor which prompts and makes it possible for nations to prosper as well as for democracy to grow and develop, the context requires that, more than ever, the state endorse, fund, provide and regulate education as its central function and strategic asset (cf. Olsen, et al., 2004).The next sections display how those global policies have been applied in Brazil and affected the academic professional.

\section{Recent changes in the Brazilian higher education setting}

Brazil is famous for being a country of contrasts. The historic social injustice is responsible for permanent vulnerabilities in all sectors of the Brazilian educational setting. Although the social composition of students today is not as elitist as before, Brazil is still striving to join the mass category.

The figures of the 2008 census show a diversified system in Brazilian $\mathrm{HE}^{8}$. Those numbers reveal that, as a trend, the public sector has diminished in size, comprising only $10.9 \%$ of all institutions. As a result of policies adopted by the Brazilian government especially after 1995, Brazilian HE system is one of the most privatized in the world (Sobrinho and Brito, 2009). As table 2 and 3 display, the private sector has become huge: it includes 2,016 institutions enrolling $74.9 \%$ of all undergraduate students.

\footnotetext{
${ }^{6}$ For a deeper knowledge of neoliberal principles and human capital theory ideas, consult Olsen, Codd, and O'Neill (2004). They argue, for example, that "neoliberalism structures the character of globalizing process". In this sense, it is their understanding that the problem resides in the way by which globalization has been managed because "the IMF, World Bank and WTO have set the rules of the game" to mostly benefit industrialized rather than developing countries.

${ }^{7}$ Marketization and privatization are realities which share closeness in nature. The former concept encompasses policies which promote deregulation and liberalizations of the educational system, fostering competition and allowing for the emergence of private providers of educational services. GATS is a multilateral organization which has endorsed educational marketization by promoting an understanding of education as a tradable commodity (Leuze, Martens and Rusconi, 2007). This agency seeks to set the legal and political guidelines that put countries under pressure toward deregulation and privatization of education (Kohlrausch and Leuze, 2007). Such influence has become a decisive trend within the process of educational national policies creation.

${ }^{8}$ Institutions are stratified into different models, multiple goals, with variable sizes and levels of quality and prestige. According to data from 2008, there are 2,252 institutions of HE, with only 183 being classified as universities. The other types of HEI (around $90 \%$ of the total of institutions) include university centers, colleges and technological institutes.
} 
Table 2: Higher education diversification in Brazil (2008)

\begin{tabular}{|c|c|c|c|c|c|}
\hline Institutions & Universities & $\begin{array}{c}\text { University } \\
\text { centers }\end{array}$ & Colleges & $\begin{array}{c}\text { Technology } \\
\text { Institutes }\end{array}$ & Total \\
\hline Brazil & 183 & 124 & 1.911 & 34 & 2.252 \\
\hline Public & 97 & 5 & 100 & 34 & 236 \\
\hline Private & 86 & 119 & 1.811 &. & 2.016 \\
\hline
\end{tabular}

Source: INEP/MEC

Table 3: Undergraduate enrollments (2008)

\begin{tabular}{|c|c|}
\hline Institutions & Enrollments \\
\hline Brazil & 5.080 .056 \\
\hline Public & 1.273 .965 \\
\hline Private & 3.806 .091 \\
\hline
\end{tabular}

Source: INEP/MEC

The 1990s created a new scenario for Brazilian HE, shaped by the interaction of two correlate processes: the opening of the Brazilian economy and the privatization process. Sobrinho and Brito (2008) highlight important factors of growth such as the "increasing economic competitiveness in a globalized world through an increase in professional training and, on the other hand, strengthening democratic values."

Ball (1988) indicates several ideological factors which underpin and explain such a scenario: learning society, knowledge-based economy, and the increasingly commoditization of knowledge. According to her, all those elements contribute to the "colonization of education policy by economic policy imperatives."

However, as Sobrinho and Brito (2008) state, expansion over this period "has faced the difficult reality of scarce financial resources in a scenario of rising demand and the requirement to meet old and new economic roles of HE."

Regulations in this new situation took place in two stages. In the first period, during President Fernando Henrique Cardoso's government (1995-2002), reform proposals for HE occurred within the context of globalization, namely, pushing institutions into better performance and into improving the relations between universities and the productive sector. In this phase, expansion of the private sector found a favorable scenario because of social factors and legal devices such as: a) centralized assessment at the Ministry of Education, intending to guarantee quality and efficiency by creating ways to monitor performance and evaluate infrastructure conditions, b) granting university autonomy also to private institutions which showed good performance in assessment and control instruments; c) stricter public budget control; d) devaluation of public HEI, e) the growth in the enrollment of preceding levels and the economic value of higher qualifications, f) abandonment of the non-dissociation principle of the trio of teaching-research-extension, considered as necessary to allow the creation of new types of HEI, expand the system and widen the possibilities to augment enrollments (Sobrinho and Brito, 2008).

In the second stage, after the election of President Luis Inácio Lula da Silva (2003), neoliberalism and globalization have been criticized, public institutions have become more dependent on public money while less accountable to external stakeholders, and private institutions have been found under strict control and stronger restrictions. 


\section{Fragmentation? of the academic profession in Brazil}

Over the 1990s, the role played by private institutions in Brazil prompted the next step of fragmentation of the professoriate ${ }^{10}$. As seen before, private institutions proliferated ${ }^{11}$, supplying teaching positions tied with the types of demands and conditions of the market-driven environment. Such institutions sought a lower scholarly qualified staff, which in turn, held lower professional expectations, and openness to accepting hour-based payment (Stromquist, et al, 2007).

Changes in the Brazilian HE regulatory framework have impacted the Brazilian academic profile as well. As the system became more selective as to academic credentials, the impact is apparent: $63 \%$ of the professors in the public sector held only a master's degree in 1994. In 2003, this figure went down to $28 \%$. Within this context, the private sector opened places for an increasing number of graduate scholars holding master's and $\mathrm{PhD}$ degrees ${ }^{12}$.

The average age of professors in Brazil was 43 years in 1992 and 45 years in 2003. In market-driven institutions the professors' age ratio is becoming even lower ${ }^{13}$. They hire professionals that help in the learning process but that additionally bring market knowledge and experience, for the courses have been chosen to comply with market demands (cf. Bonventi, 2007). The bulk of the academic body is comprised of young professionals ${ }^{14}$, having little or no educational experience.

In Brazilian public institutions faculty have stable contracts as a result of their status as civil servants. In the private sector, job stability is seldom recognized.

\footnotetext{
${ }^{9}$ The institutional differentiation process have driven what Stromquist, et al. (2007) call "fragmentation" of the academic profession in Brazil.

${ }^{10}$ Exacerbation of the division between public and private institutions is another aspect of the massification process. Within this dynamic, the public sector has been partially able to protect its academic body, while the private sector moves towards an "unstable professoriate, poorly paid, hired mostly on a per-hour basis, and for whom sharing in academic governance is a distant dream" (Stromquist, et. al., 2007).

${ }^{11}$ This sector is mostly composed of small, for-profit, teaching-oriented, non-university schools (Sobrinho and Brito, 2009).

${ }^{12}$ Nonetheless, it would be a misrepresentation to assume that employment conditions had largely improved in the sector. Facing those new exigencies, the response of private institutions was "arranged" to meet official demands. Limited by competition in the market, they were unable to raise tuitions to cover the extra expenses involved in hiring better qualified staff and offering better contract conditions. In this situation, the most usual procedure was to employ the minimal number of graduate scholars to comply with regulatory requirements. From the faculty standpoint, a paradox emerges. As one invests in graduate studies aiming at improving the chances for access to better working conditions, one may also become less "employable", for as an institution fulfills the minimal legal requirements of scholars with graduate qualifications, it may not be willing to hire such highly trained academics. Thus, an improvement of one's academic profile may turn into a risky investment.

${ }^{13}$ According to Bonventi, in 2007, out of 218,823 professors who worked in the private sector, young professors were more numerous than in the public sector. In the private sector, those under 40 years of age represent $47 \%$ of the total, whereas in the public sector out of the 115.865 scholars the same age group represent $31.5 \%$ (source: Private Higher education System of Information, Sindata).

${ }^{14}$ Financial reasons explain this scenario. Hiring professionals with proficiency, seniority and greater dedication is more expensive than hiring many newly-graduated teachers with low salaries to teach a massive student population. However, the difference is clear: in an academic unit where the teaching responsibility resides in full-time professors (and not lecturers) with better qualifications (graduate degrees), academic quality is exponentially enhanced.
} 
Table 4: Administrative category (2004)

\begin{tabular}{|c|c|c|c|c|c|}
\hline $\begin{array}{c}\text { Work regime / } \\
\text { Institution }\end{array}$ & \multicolumn{2}{c|}{ Public } & \multicolumn{2}{c|}{ Private } & Total \\
\hline Hourly based contract & $8 \%$ & 74,629 & $62 \%$ & 27,362 & 127,666 \\
\hline Partial time contract & $18 \%$ & 17,980 & $24 \%$ & 45,335 & 63,315 \\
\hline Full-time contract & $74 \%$ & 7,815 & $14 \%$ & 119,851 & 102,261 \\
\hline Total & & 100,424 & & 192,818 & 293,242 \\
\hline
\end{tabular}

Source: MEC, INEP/CAPES

Working conditions and academic qualification are two other relevant indicators regarding faculty quality in a HEI. As shown in table 4, professors in the public sector are mostly hired as full-time teachers $(74 \%)$, whereas only $8 \%$ are in the hour-based hiring group. HEI in the private sector show the predominance of partial (24\%) and hourly (62\%) contracts ${ }^{15}$. Fulltime contracts ensure a good income level for faculty in the public sector and salaries, even at state universities, tend to follow federal standards. Thus, professors in this sector are rarely found holding other academic positions (Balbachevsky and Quinteiro, 2002). Teaching load is prone to be low in this sector as well.

On the contrary, full-time contracts are seldom found in the private sector, whose institutions are staffed by teachers paid on hourly basis and who have teaching as a complementary job. Such a situation weakens teaching quality, for less time tends to be spent on teaching than on activities outside the academic world ${ }^{16}$. Faculty members at private institutions who have teaching as their principal professional activity earn their living by teaching a great number of classes, with heavy individual teaching loads.

Analysis over time demonstrates that consistent Improvement of the academic profile in private institutions has occurred in the last decade in Brazil. As the 1995 Brazilian Education Act established new institutional accreditation criteria with heavy emphasis on faculty academic qualification and required a minimum percentage of teachers holding full-time contracts, private institutions were prompted to offer enhanced contracts to attract better qualified professors, including: higher salaries, job stability, and research support ${ }^{17}$.

Table 5 presents variations among public and private institutions as to faculty qualification. As per the distribution in the system, in 2006, most of the $22.3 \%$ academics holding doctorates in Brazilian HEI were in the public sector. Indeed, whereas the public sector offered only $33.7 \%$ of all academic positions, $63.4 \%$ of all professors' doctorate holders worked in a public institution. Conversely, as $66.2 \%$ of all academic posts were found in the private sector, only $35.8 \%$ of academics held a Ph.D. in this subsystem (Balbachevsky; Schwartzman; Alves; Santos, and Duarte 2009).

\footnotetext{
15 The small proportion of full-time professors in the private sector usually leads to reduced faculty control over curriculum (Levy, 2006).

${ }^{16}$ Balbachevsky and Quinteiro, 2002.

${ }^{17}$ These trends and improvements are visible in numbers: within the period of years from 1992 to 2003 , full-time positions varied from $72 \%$ to $82 \%$ in the public sector and $10 \%$ to $22 \%$ in the private sector, respectively (Balbachevsky and Holzhacker, 2004).
} 
Table 5: Faculty qualification in public and private institutions (in \%)

\begin{tabular}{|c|c|c|c|}
\hline Institution & Degree & 1992 & 2003 \\
\hline \multirow{3}{*}{ Public } & Bachelor & 21 & 4.6 \\
\cline { 2 - 4 } & Doctorate & 22 & 39 \\
\hline Private & Bachelor & 38 & 7 \\
\cline { 2 - 4 } & Master & 20 & 41 \\
\cline { 2 - 4 } & Doctorate & 8 & 25 \\
\hline
\end{tabular}

Source: Balbachevsky and Holzhacker (2004)

The way in which the world of scientific publishing is organized discourages scientific communities from rising in developing countries. As part of the periphery in HE world, academics in Brazil strive to keep abreast of world science and are found in apparent competitive disadvantage. No wonder, Professors' teaching load is heavy and research is performed only at a small number of universities. The number of scientific articles reached 30,451 in 2008, which places Brazil in the 13th position in the scientific publishing world rank (Jahn, 2010). But when it comes to how often each text is quoted by other researchers, the result is poor. This mainly happens for a reason: $60 \%$ of the articles published in Brazil are in Portuguese. Brazilian academic market is still closed and inner-oriented (Balbachevsky, Schwartzman et alia, 2009). The influence of globalization has its impact also in this sector. Due to the fact that most of the research published in Brazilian journals has no English version, its visibility gets reduced. "Number of citations per paper doubles when text is in English" (Righetti, 2011). Guo and Beckett (2008) explain the phenomenon by conveying that "hegemony of English as a global language" is another form of promoting neo-colonialism and inequity. According to those scholars, through the increasingly monopoly of English ${ }^{18}$ worldwide, it has damaged local and first languages as well as local knowledge.

Brazilian academics have learned to live in a new culture of accountability ${ }^{19}$. In such a context, assessment of academic work has become a common process, with evaluation of all dimensions of university work putting stress on faculty members to a greater extent and threatening academic autonomy. Bottery (2006) is in accord with Hargreaves when the later states that "external, quantitavite low-trust forms of accountability based upon private-sector strategies of 'exit' rather than of public-sector values of 'voice', linked to systems of targets and performativity, have generated poor morale in the teaching profession." In such a context, Brazil has promoted efforts to increase the quality of its academic staff by increasing the minimum qualifications for appointments, with an increasing perception of the importance of graduate studies as a requirement for appointment as a professor at the postsecondary level.

The reforms of 1990s have also impacted academics' relationships with their institutions. Some new universities replaced (a) the traditional university government with an administrative

\footnotetext{
18 "English has become the dominant global language of communication, business, aviation, entertainment, diplomacy, and the internet" (Guo and Beckett, 2008). It has also become the hegemonic academic and scientific publications language. Indeed, Altbach (2009) concurs to this view by stating that "the role of English affects higher education policy and the work of individual students and scholars. Obviously, the place of English at the pinnacle of scientific communication gives a significant advantage to the United States and the United Kingdom and to other wealthy English-speaking countries."

${ }^{19}$ As Bottery (2006) points out "educators may experience greater control and direction of their work" as political globalization affects their professional life.
} 
body (and new management models) committed to obtaining alternative funding resources, and (b) unrestricted admission for a selective one. On the other hand, the main leadership positions were occupied by administrators due to the inexorable demands and complexities of the management process ${ }^{20}$.

Increasing bureaucratic procedures along with more diverse and powerful administrative structures have influenced the situation of the academics as well by diminishing their authority, lessening faculty participation in institutional governance and weakening the sense of community among academics. Ball (1988) reckons how such processes are tied to the strong influence of "new managerialism, that is the insertion of the theories and techniques of business management and 'the culture of excellence' into public sector institutions." In the educational sector, market driven reform has led to the replacement of bureau-professional organizational regimes by corporate culture (Ball, 1988). Under this view, educational institutions are expected to become business-oriented organizations in their methods, practices, values, principles and social relationships ${ }^{21}$.

Regarding this issue, Olsen, et al. (2004) point out that neoliberalism has promoted a culture based on values like "individualism, competitiveness and mistrust." They also reckon how those values and the highlighting of managerialism and performativity has damaged teacher's professionalism ${ }^{22}$. Under the concepts of neoliberalism ideology, professors are perceived as "managed professionals who can operate efficiently and effectively within global educational markets." (idem)

\section{Conclusion}

The data presented in this paper convey that educational reforms led by neoliberal policies are at the origin of the movement toward the degradation and loss of prestige of the academics. These reforms occurred within a context of profound change in the conceptualization of the role that the State plays in the economic and social development of modern knowledge societies within the increasing globalization process. Undeniably, the so-called crisis of the "Welfare State" is at the heart of the educational changes in Brazil (Mollis, 2008).

From 1995 onwards, an international agenda endorsed by agencies like the World Bank and the Inter-American Development Bank was implemented. This agenda aimed basically at diminishing government investments in education and science along with a careful control of distribution of financial resources, expansion of private institutions, the enactment of a HE Act setting new rules for tertiary education, comprising assessment and accreditation systems, and programs to improve quality with its respective executive agencies (Mollis, 2008).

As expansion and privatization predominated as trends throughout Latin America in the 1990s, it was not different in Brazil. Massification of HE in Brazil occurred mostly tied to the private sector.

\footnotetext{
${ }^{20}$ Bottery reminds us that as educational policies have been driven by reduced state investments and cuts, administrators and senior academics pressure professors to develop entrepreneurial skills, which in turn diminish their capacity "to support traditional university values of open inquiry and a community of scholars."

${ }^{21}$ According to Bottery (2006), principles like "efficiency, economy and profit" which guide practices in the private sector are very likely to collide with those which constitute public sector's values such as "equity and care".

${ }^{22}$ The traditional profile of a professor has been modified as "privatization has placed pressure on academics to generate income for themselves and for the university through consulting and other extra-academic activities. Marketization has forced academics to become more aware of students' curricular interests and market trends. Professors have also been encouraged to engage in entrepreneurial activities." (Altbach, 2009)
} 
In such a context, lack of prestige, of job security, and of career planning are characteristics of Brazilian professorate. The majority of the professorate is made up of part-time staff who teach a few courses and whose links to the institution are weak. Such context is changing the concept and the status of the professoriate in this country. It is reasonable to be suspicious about the quality and value of the educational service provided in a country where the professoriate finds itself in such deteriorated work conditions. This current situation is in clear contrast with a widespread consciousness concerning the importance of HE for the future of knowledge-based societies as well as the centrality of teaching quality regarding the relevance and success of the academic endeavor.

In order for the academic body to get back on track and recover its quality and prestige, thus, becoming a true profession again, new policies must be implemented. Teachers' qualification, adequate payment and status must be promoted. The number of part-time teachers must be reduced, replaced by a significant group of full-time professors on an appropriate career path. Salaries must be high enough to attract talented scholars and to retain them. Accountability and assessment process must be properly employed. Measures for involving faculty in academic decision-making need to be implemented to guarantee that the staffs have significant participation in institutional leadership.

If such progress is to happen, policymakers and governments must see the academic profession as essential to providing effective teaching and learning in the knowledge society. Furthermore, professors must recover their political and organizational capacity, and protest against the situation facing them, thus helping the whole society to grow in awareness regarding these challenges. This aspect of the academic profession demands further study in order to understand how faculty members have reacted to the situation they are currently facing.

As a sad and deplorable result of this whole process, a fracture has evolved within HEI, as two groups of professionals occupy the academic arena: a tiny and prestigious nucleus of faculty represented by elite professors who work in prestigious universities, and a large group of less qualified and poorly compensated lecturers employed by low-status institutions.

\section{References}

Alfinito, Solange (2007). Educação superior no Brasil: análise do histórico recente (19942003).

Brasília, DF: Instituto Nacional de Estudos e Pesquisas Educacionais Anísio Teixeira.

Altbach, Philip G., Liz Reisberg \& Laura E. Rumbley (2009). Trends in Global Higher

Education: Tracking an Academic Revolution. Report Prepared for the UNESCO World

Conference on HigherEducation. Paris: The United Nations Educational, Scientific and Cultural Organization.

Altbach, Philip (2009). "It's the Faculty, Stupid! The centrality of the academic profession", International Higher Education, Spring, 2009. Retrieved February 24, 2010 from http://www.bc.edu/bc_org/avp/soe/cihe/

Balbachevsky, Elizabeth \& Quinteiro, Maria da Conceição (2002). The Changing Academic Workplace in Brazil in Altbach, Philip (editor),The decline of the guru. Chestnut Hill: Boston College, Center for International Higher Education.

Balbachevsky, Elizabeth \& Holzhacker, Denilde Oliveira (2004). The Academic Profession in Brazil in International Higher Education, Spring 2004. Retrieved February 24, 2010 from http://www.bc.edu/bc_org/avp/soe/cihe/ 
Balbachevsky, Elizabeth; Schwartzman, Simon; Alves, Nathalia Novaes; Santos, Dante Filipe Felgueiras dos; \& Duarte, Tiago Silva Birkholz (2009). Brazilian Academic Profession: some recent trends. The Changing Academic Profession in International Comparative and Quantitative Perspectives. RIHE International Seminar Reports, 12, 327-344. Retrieved March 4, 2010 from www.iea.usp.br/iea/english/articles

Ball, Stephen, J (1988). Big policies/small world: an introduction to international perspectives in education policy. Comparative education, v 34, n. 2, 119-130.

Barreyro, Gladys Beatriz (2008). Mapa do Ensino Superior Privado. Brasília: Instituto Nacional de Estudos e Pesquisas Educacionais Anísio Teixeira.

Bonventti, Rodolfo C. (n.d.). Entre dois Saberes. Retrieved March 3, 2010 from http://revistaensinosuperior.uol.com.br/textos.asp?codigo $=12485$

Borda, Gilson Zehetmeyer (2007). Capital social organizacional: a "confiança" nas instituições de ensino superior em Brasília. Doctorate dissertation in Sociology. Brasilia, DF: Universidade de Brasília.

Bottery, Mike (2006). Educational leaders in a globalising world: a new set of priorities? School leadership and management, v. 26, n. 1, 5-22.

Guo, Yan \& Beckett, Gulbahar (2008). The hegemony of English as a global language in Abdi, Ali \& Shibao, Guo (2008). Education and social development: global issues and analyses. Rotterdam, the Netherlands: Sense publishers.

Jahn, Filipe. Doutorado em discussão. Retrieved March 01, 2010 from http://revistaensinosuperior.uol.com.br/textos.asp?codigo $=12413$

Jareta, Gabriel (n.d.). Alunos 'número um'. Retrieved March 01, 2010 from http://revistaensinosuperior.uol.com.br/textos.asp?codigo $=11980$

INEP. Mapa do ensino privado no Brasil. Retrieved March 01, 2010 from http://www.publicacoes.inep.gov.br/arquivos/\{ 8ED30485-A41C-4E03-AD54A75FB66FFBC3\}_Relatosdepesquisa37.pdf

Kuri, Rocio Grediaga (2005). Academic career: teaching evaluation, productivity assessment and retiring systems. Unintended consequences of new measures for the renewal and development of the academic profession. Document presented at the OECD Conference On Trends in the Management of Human Resources in Higher Education. Paris.

Kohlrausch, Bettina \& Leuze, Kathrin (2007). Implications of marketization for the perception of education as public or private good in Leuze, Martens \& Rusconi, (2007). New arenas of education governance: the impact of international organizations and markets. New York (NY): Palgrave.

Leuze, Kathrin; Martens, Kerstin \& Rusconi, Alessandra (2007). New arenas of education governance: the impact of international organizations and markets. New York (NY): Palgrave.

Levy, Daniel (2006). The Private Fit in the Higher Education Landscape in J. Forest \& P. Altbach, (eds.), International Handbook of Higher Education, 18. Dordrecht, Netherlands: Springer.

Maisonnave, Fabiano. Na AL, Brasil tem menos alunos em faculdade publica (In Latin America, Brazil has less students in public institutions), in Folha de São Paulo, 06/07/2008.

Marquis, Carlos (2002). Universities and professors in Argentina: changes and challenges in in Altbach, Philip (editor) The decline of the guru. Chestnut Hill: Boston College, Center for International Higher Education. 
Mollis, Marcela (2009). Higher Education Reforms in Argentina: Towards the New Millennium. in Segrera, Francisco López; Brock, Colin; Sobrinho, José Dias (editors). Higher education in Latin America and the Caribbean, Caracas: UNESCO-IESALC.

Olsen, Mark; Codd, John \& O’Neill, Anne-Marie (2004). Education policy: globalization, citizenship and democracy. Thousand Oaks, CA: Sage.

Righetti, Sabine. Língua portuguesa esconde ciência nacional in Folha de São Paulo, 09/20/2011.

Santos, Boaventura S. (2004). Interview. Retrieved September, 18, 2011 from: www.ces.fe.uc.pt/BSS/documentos/JornalOGLOBNov2004.pdf.

Scocuglia, Afonso Celso (2006). A pedagogia social de Paulo Freire como contraponto da pedagogia globalizada. In Faculdade de Educação, Universidade de São Paulo. I Congresso Internacional de Pedagogia Social, retrieved September, 29, 2011 from: $<$ http://www.proceedings.scielo.br/scielo.php?script=sci_arttext\&pid=MSC00000000920 06000100002\&lng=en\&nrm=abn>.

Sobrinho, José Dias \& Brito, Marcia Regina Ferreira (2009). Higher education in Brazil: main trends and challenges in Segrera, Francisco López; Brock, Colin; Sobrinho, José Dias (eds). Higher education in Latin America and the Caribbean, Caracas: UNESCOIESALC.

Stromquist, Nelly P.; Gil-Anton, Manuel; Colatrella, Carol; Mabokela, Reitumtse Obakeng; Smolentseva, Anna; Balbachevsky, Elizabeth (2007). The Contemporary Professoriate: Towards a Diversified or Segmented Profession? In Higher Education Quarterly, v 61, $n$ 2, 114-135.

The World Bank (2000). Higher Education in Developing Countries: Peril and Promise. Washington, DC: The World Bank. 